\title{
EVALUASI DAYA GABUNG PERSILANGAN JAGUNG DENGAN METODE DIALLEL
}

\author{
Heruna Tanty \\ Mathematics \& Statistics Department, School of Computer Science, Binus University \\ Jl. K. H. Syahdan No. 9 Palmerah Jakarta Barat 11480 \\ herunatanty@yahoo.com
}

\begin{abstract}
Corn is one of the plants that people use for food. Therefore, to obtain a superior maize crop a research is required. The formation of hybrid maize varieties can be created through a series of crosses among tetua (the parent plant). This research is conducted for selecting tetua which can give good results based on testing the general affinity and specific affinity with Diallel analysis. General affinity indicates the suitability level of an elder for various crossing partners. While special affinity indicates a specific level of suitability partner. The data of general affinity and specific affinity test is obtained from the results of crossbreeding experiments using seven tetuas. To hold a faster and a more accurate analysis in calculating the general affinity and affinity cross plants, we use a computer system.
\end{abstract}

Keywords: hybrid, Diallel analysis, general affinity, special affinity

\begin{abstract}
ABSTRAK
Jagung adalah salah satu tanaman yang digunakan sebagai bahan pangan oleh masyarakat. Oleh karena itu, untuk mendapatkan tanaman jagung yang unggul perlu diadakan penelitian. Pembentukan varietas jagung hibrida dapat dihasilkan melalui serangkaian persilangan di antara tetua (induk). Penelitian dilakukan untuk pemilihan tetua yang dapat memberikan hasil yang baik berdasarkan uji daya gabung umum dan daya gabung khusus dengan metode analisis Diallel. Daya gabung umum menunjukkan tingkat kesesuaian suatu tetua terhadap berbagai pasangan persilangan. Sedangkan daya gabung khusus menunjukkan tingkat kesesuaian pasangan yang spesifik. Data uji daya gabung umum dan khusus telah dilakukan dari hasil percobaan persilangan yang menggunakan 7 tetua. Untuk mempercepat dan menghasilkan analisis yang akurat dalam menghitung daya gabung umum dan daya gabung khusus persilangan tanaman digunakan sistem komputer.
\end{abstract}

Kata kunci: hibrida, analisis Diallel, daya gabung umum, daya gabung khusus 


\section{PENDAHULUAN}

Indonesia merupakan negara yang berpenduduk padat dan sebagian kebutuhan pangannya dipenuhi melalui budidaya pertanian. Salah satu hasil pertanian yang banyak digunakan sebagai makanan pokok oleh masyarakat Indonesia adalah jagung. Untuk menemukan suatu tanaman unggul, maka perlu dicari teknologi peningkatan produktivitas tanaman melalui serangkaian penelitian. Dalam penelitian ini akan dianalisis hasil persilangan tanaman jagung melalui model Diallel berbasis komputer untuk menjawab permasalahan: Apakah ada varietas jagung yang unggul berdasarkan Daya Gabung Umum dan Daya Gabung Khusus?

Adapun tujuan penelitian ini adalah: (1) memperoleh varietas jagung yang unggul dari hasil persilangan tanaman jagung; (2) mempercepat sistem perhitungan analisis data hasil penelitian agar peneliti dapat mengambil kebijakan secara cepat dan tepat; (3) mendapatkan pasangan persilangan jagung yang menghasilkan varietas unggul.

\section{Tinjauan Pustaka}

\section{Deskripsi Jagung}

Jagung merupakan tanaman semusim determinan, dan satu siklus hidupnya diselesaikan dalam 80-150 hari. Paruh pertama dari siklus merupakan tahap pertumbuhan vegetatif dan paruh kedua untuk pertumbuhan generatif. Tanaman jagung termasuk famili rumput-rumputan dari subfamili myadeae. Dua famili yang berdekatan dengan jagung adalah teosinte dan tripsacum yang diduga merupakan asal dari tanaman jagung. Teosinte berasal dari Meksiko dan Guatemala sebagai tumbuhan liar di daerah perkebunan jagung. Jagung memiliki akar serabut dengan tiga macam akar, yaitu (a) akar seminal, (b) akar adventif, (c) akar kait atau penyangga. Akar seminal adalah akar yang berkembang dari radikula dan embrio. Akar adventif adalah akar yang semula berkembang dari buku di ujung mesokotil, kemudian set akar adventif berkembang dari tiap buku secara berurutan dan terus ke atas antara 7-10 buku, semuanya di bawah permukaan tanah. Akar kait atau penyangga adalah akar adventif yang muncul pada dua atau tiga buku di atas permukaan tanah. Perkembangan akar jagung tergantung pada varietas, pengolahan tanah, fisik dan kimia tanah, keadaan air tanah, dan pemupukan.

Tanaman jagung mempunyai batang yang tidak bercabang, berbentuk silindris, dan terdiri atas sejumlah ruas dan buku ruas. Batang memiliki tiga komponen jaringan utama, yaitu kulit (epidermis), jaringan pembuluh (vaskuler bundles), dan pusat batang (pith). Vaskuler bundles tertata dalam lingkaran konsentris dengan kepadatan bundles yang tinggi, lingkaran-lingkaran menuju pericarp dekat epidermis. Kepadatan bundles berkurang begitu mendekati pusat batang. Konsentrasi vaskuler bundles yang tinggi di bawah epidermis menyebabkan batang tahan rebah.

Daun terdiri atas helaian daun, ligula, dan pelepah daun yang erat melekat pada batang. Jumlah daun sama dengan buku batang. Jumlah daun umumnya berkisar antara 10-18 helai. Tanaman jagung di daerah tropis mempunyai jumlah daun relatif lebih banyak dibanding di daerah beriklim sedang (Paliwal, 2000). Lebar helai daun dikategorikan mulai dari sangat sempit $(<5 \mathrm{~cm})$, sempit $(5,1-$ $7 \mathrm{~cm})$, sedang $(7,1 .-9 \mathrm{~cm})$, lebar $(9,1-11 \mathrm{~cm})$, hingga sangat lebar $(>11 \mathrm{~cm})$. Bentuk ujung daun berbeda, yaitu runcing, runcing agak bulat, bulat agak tumpul, dan tumpul. Berdasarkan letak posisi daun terdapat dua tipe daun jagung, yaitu tegak (errect) dan menggantung (pendant). Jagung disebut juga tanaman berumah satu karena bunga jantan dan betinanya terdapat dalam satu tanaman. Bunga betina, tongkol, muncul dari aksila tajuk. Bunga jantan berkembang dari titik tumbuh apikal di ujung tanaman. Rambut jagung (silk) adalah pemanjangan dari saluran stylar ovary yang matang pada tongkol. Rambut jagung tumbuh dengan panjang hingga $30.5 \mathrm{~cm}$ atau lebih sehingga keluar dari ujung kelobot. Panjang rambut jagung bergantung pada panjang tongkol dan kelobot. 
Penyerbukan pada jagung terjadi bila serbuk sari dan bunga jantan menempel pada rambut tongkol. Hampir $95 \%$ dari persarian tersebut berasal dari serbuk tanaman lain, dan hanya $5 \%$ yang berasal dari serbuk tanaman sendiri. Oleh karena itu, tanaman jagung disebut tanaman bersari silang, dimana sebagian besar dari serbuk sari berasal dari tanaman lain. Terlepasnya serbuk sari berlangsung 3-6 hari, bergantung pada varietas, suhu, dan kelembaban. Penyerbukan selesai dalam 24-36 jam dan biji mulai terbentuk sesudah 10-15 hari. Setelah penyerbukan, warna rambut tongkol berubah menjadi coklat dan kemudian kering.

Tanaman jagung mempunyai satu atau dua tongkol, tergantung varietas. Tongkol jagung yang terletak pada bagian atas umumnya lebih dahulu terbentuk dan lebih besar dibanding yang terletak pada bagian bawah. Setiap tongkol terdiri atas 10-16 baris biji yang jumlahnya selalu genap. Biji jagung terdiri atas tiga bagian utama, yaitu (a) pericarp, berupa lapisan luar yang tipis, berfungsi mencegah embrio dari organisme peganggu dan kehilangan air. (b) endosperm, sebagai cadangan makanan, mencapai $75 \%$ dari bobot biji yang mengandung $90 \%$ pati dan $10 \%$ protein, mineral, minyak, dan lainnya; dan (c) embrio (lembaga), sebagai miniatur tanaman yang terdiri atas plamule, akar radikal, scutelum, dan koleoptil (Hardman and Gunsolus, 1998).

\section{Pembentukan Varietas Jagung Hibrida}

Tanaman jagung mempunyai komposisi genetik yang sangat dinamis karena cara penyerbukan bunganya menyilang. Varietas hibrida merupakan generasi pertama hasil persilangan antara tetua berupa galur inbrida. Varietas hibrida dapat dibentuk pada

tanaman menyerbuk sendiri maupun menyerbuk silang.

Pada awal penggunaan jagung hibrida, varietas yang dilepas adalah hibrida silang puncak ganda, namun sekarang lebih banyak hibrida silang tunggal. Varietas hibrida merupakan generasi pertama (F1) hasil persilangan antara tetua berupa galur inbrida atau varietas bersari bebas yang berbeda genotype. Hal yang perlu dilakukan dalam pemuliaan varietas hibrida adalah pembuatan galur inbrida, yakni galur tetua yang homozigot melalui silang dalam (inbreeding) pada tanaman menyerbuk silang. Dalam pembuatan varietas hibrida dua galur yang homozigot disilangkan dan diperoleh generasi F1 yang heterozigot, kemudian ditanam sebagai varietas hibrida.

Terdapat tiga langkah dalam pembentukan varietas hibrida: (1) membentuk galur inbrida, secara normal dengan melakukan beberapa generasi silang dalam (inbreeding) pada species tanaman menyerbuk silang; (2) menilai galur inbreed berdasarkan uji daya gabung umum dan daya gabung khusus untuk menentukan kombinasi-kombinasi varietas hibrida; (3) menyilangkan pasangan galur murni yang tidak berkerabat untuk membentuk varietas hibrida F1.

Terdapat beberapa jenis jagung hibrida, yaitu silang puncak, silang tunggal, dan silang ganda. Hibrida silang ganda memiliki hasil lebih rendah dan fenotipe tanaman kurang seragam dibandingkan dengan silang tunggal. Hibrida silang tunggal memiliki hasil dan daya adaptasi lingkungan yang tinggi. Hibrida silang tiga jalur dan modifikasi silang tunggal lebih banyak dipasarkan. Untuk membuat silang ganda diperlukan dua hibrida silang tunggal dari empat galur inbrida yang berbeda dan hasilnya tinggi. Untuk pembentukan hibrida silang tiga jalur diperlukan satu hibrida silang tunggal dan satu inbrida.

\section{Rancangan Acak Kelompok Lengkap}

Rancangan acak kelompok lengkap merupakan salah satu rancangan percobaan yang paling luas digunakan dalam penelitian pertanian. Kadang-kadang mungkin untuk membuat asumsi bahwa tidak ada perbedaan reciprocals (persilangan kebalikannya). Di dalam beberapa kasus tidak akan 
diperlukan untuk membuat persilangan reciprocals. Kemudian tetua dan 1 set dari F1 dianalisis. Dengan $\mathrm{n}$ tetua (induk), total masukkan untuk dianalisis di dalam metode ini adalah

$$
\{\mathrm{n}(\mathrm{n}+1)\} / 2
$$

Ada beberapa langkah yang dilakukan di metode ini menurut Singh dan Chaudhary (1979). Pertama, menganalisis perbedaan nyata dari genotipe, dengan cara menghitung jumlah kuadrat dan membuat anova. Penting untuk diingat bahwa untuk setiap ulangan terdapat satu pengamatan. Ini menunjukkan bahwa variabel total bisa dikelompokkan ke dalam komponen seperti ulangan, perlakuan, dan eror. Langkah-langkah untuk menduga jumlah kuadrat yaitu seperti membuat anova di dalam rancangan acak kelompok lengkap. Kedua, membuat analisis daya gabung dengan menduga jumlah kuadrat. Hitung jumlah kuadrat daya gabung umum dengan

$$
(\mathrm{Gca})=\frac{1}{n+2}\left[\sum\left(Y_{i .}+Y_{i i}\right)^{2}-\frac{4}{n} Y . .\right]
$$

\section{Rancangan Acak Kelompok Lengkap}

Rancangan acak kelompok lengkap merupakan salah satu rancangan percobaan yang paling luas digunakan dalam penelitian pertanian. Kadang-kadang mungkin untuk membuat asumsi bahwa tidak ada perbedaan reciprocals (persilangan kebalikannya). Di dalam beberapa kasus tidak akan diperlukan untuk membuat persilangan reciprocals. Kemudian tetua dan 1 set dari F1 dianalisis. Dengan $\mathrm{n}$ tetua (induk), total masukkan untuk dianalisis di dalam metode ini adalah

$$
\{\mathrm{n}(\mathrm{n}+1)\} / 2
$$

Ada beberapa langkah yang dilakukan di metode ini menurut Singh dan Chaudhary (1979). Pertama, menganalisis perbedaan nyata dari genotipe, dengan cara menghitung jumlah kuadrat dan membuat anova. Penting untuk diingat bahwa untuk setiap ulangan terdapat satu pengamatan. Ini menunjukkan bahwa variabel total bisa dikelompokkan ke dalam komponen seperti ulangan, perlakuan, dan eror. Langkah-langkah untuk menduga jumlah kuadrat yaitu seperti membuat anova di dalam rancangan acak kelompok lengkap. Kedua, membuat analisis daya gabung dengan menduga jumlah kuadrat. Hitung jumlah kuadrat daya gabung umum dengan

$$
(\mathrm{Gca})=\frac{1}{n+2}\left[\sum\left(Y_{i .}+Y_{i i}\right)^{2}-\frac{4}{n} Y . .\right]
$$

Kemudian hitung jumlah kuadrat daya gabung khusus dengan

$$
(\mathrm{Sca})=\sum \sum Y_{i j}{ }^{2}-\frac{1}{n+2} \sum\left(Y_{i .}+Y_{i i i}\right)^{2}+\frac{2}{(n+1)(n+2)} Y^{2} .
$$

Selanjutnya, hitung jumlah kuadrat galat dengan

$$
\text { galat }=\text { S.S galat } / \mathrm{r}
$$

Tabel 1

Anova Gca dan Sca

\begin{tabular}{llll}
\hline Sumber (Source) & Db (df) & Varians (Variance) & Fhitung \\
\hline DGU (GCA) & $\mathrm{n}-1$ & $M_{g}$ & $M_{g} / M_{e}$ \\
DGK (SCA) & $\mathrm{n}(\mathrm{n}-1) / 2$ & $M_{s}$ & $M_{s} / M_{e}$
\end{tabular}


$\mathrm{F}_{\text {hitung }}=M_{g} / M_{e}$ mengikuti sebaran $\mathrm{F}$ dengan derajat bebas pembilang sebesar n-1 dan derajat bebas penyebut sebesar (t-1)(r-1). Jika nilai $\mathrm{F}_{\text {hitung }}$ lebih besar dari $\mathrm{F}_{\alpha, \mathrm{db} 1, \mathrm{db} 2}$ maka hipotesis nol ditolak dan berlaku sebaliknya.

$\mathrm{F}_{\text {hitung }}=M_{s} / M_{e}$ mengikuti sebaran $\mathrm{F}$ dengan derajat bebas pembilang sebesar $\mathrm{r}-1$ dan derajat bebas penyebut sebesar (t-1)(r-1). Jika nilai $\mathrm{F}_{\text {hitung }}$ lebih besar dari $\mathrm{F}_{\alpha, \mathrm{db} 1, \mathrm{db} 2}$ maka hipotesis nol ditolak dan berlaku sebaliknya.

Ketiga, menduga efek daya gabung umum dan daya gabung khusus.

Efek Daya gabung umum $=g_{n}=\frac{1}{n+2}\left[\sum\left(Y_{i .}+Y_{i i}\right)-\frac{2}{n} Y ..\right]$

Efek daya gabung umum menunjukkan tingkat kesesuaian suatu tetua terhadap berbagai pasangan persilangan.

Efek daya gabung khusus $=S_{i j}=Y_{i j}-\frac{1}{n+2}\left(Y_{i .}+Y_{i i}+Y_{. j}+Y_{i j}\right)+\frac{2}{(n+1)(n+2)} Y_{. .}$

Efek daya gabung khusus menunjukkan tingkat kesesuaian pasangan yang spesifik.

\section{METODE}

Data yang dikumpulkan adalah data pertumbuhan dan hasil biji dari persilangan jagung dari 7 tetua. Data yang dikumpulkan jenis yaitu bobot 200 butir, tinggi tanaman, umur bunga jantan, umur bunga betina, hasil jagung, dan umur panen. Data dikumpulkan dari percobaan yang dilaksanakan di lapang di Bogor. Percobaan dilaksanakan dalam rancangan acak kelompok dengan 28 perlakuan dalam 3 ulangan.

Teknik analisis data yang digunakan untuk melihat tanaman jagung manakah yang menghasilkan persilangan terbaik adalah analisis Diallel. Data-data yang didapat dari observasi lapangan kemudian diolah dan disusun sedemikian rupa, sehingga didapat hasil rata-ratanya. Setelah didapat hasil rata-ratanya kemudian mencari Anova setiap data persilangan jagung yang menggunakan prinsip rancangan acak kelompok. Dilanjutkan dengan menghitung Anova daya gabung umum dan daya gabung khusus, dan kemudian menduga efek daya gabung umum dan daya gabung khususnya.

\section{HASIL DAN PEMBAHASAN}

\section{Data Karakteristik Tanaman Jagung Hasil Persilangan}

Data yang telah berhasil dikumpulkan oleh penulis di BB BIOGEN diperoleh hasil persilangan antara 7 jenis tanaman jagung dalam hal umur panen, hasil jagung, umur bunga betina, umur bunga jantan, tinggi tanaman, dan bobot 200 butir yang diulang sebanyak 3 kelompok (Tabel 2). 
Tabel 2.

Rata-Rata Karakteristik Tanaman Jagung Hasil Persilangan

\begin{tabular}{|c|c|c|c|c|c|c|c|c|c|}
\hline $\begin{array}{l}\text { Tetua } \\
\text { Jantan }\end{array}$ & $\begin{array}{l}\text { Tetua } \\
\text { Betina }\end{array}$ & $\begin{array}{ll}\text { Bobot } & 200 \\
\text { Butir } & \\
\end{array}$ & $\begin{array}{l}\text { Tinggi } \\
\text { tanaman }\end{array}$ & $\begin{array}{l}\text { Umur } \\
\text { Jantan }\end{array}$ & Bunga & $\begin{array}{l}\text { Umur } \\
\text { Betina }\end{array}$ & Bunga & $\begin{array}{l}\text { Hasil } \\
\text { jagung }\end{array}$ & $\begin{array}{l}\text { Umur } \\
\text { Panen }\end{array}$ \\
\hline A & A & 54.00 & 119.47 & 59.67 & & 62.67 & & 0.49 & 93.00 \\
\hline B & A & 62.67 & 148.53 & 66.00 & & 68.67 & & 1.92 & 106.00 \\
\hline $\mathrm{C}$ & A & 62.67 & 153.67 & 68.00 & & 71.67 & & 2.15 & 105.00 \\
\hline $\mathrm{D}$ & A & 69.33 & 165.73 & 68.00 & & 72.33 & & 2.02 & 106.00 \\
\hline $\mathrm{E}$ & A & 67.33 & 152.27 & 68.00 & & 75.00 & & 2.05 & 106.00 \\
\hline $\mathrm{F}$ & A & 69.33 & 157.13 & 70.00 & & 74.33 & & 1.69 & 107.00 \\
\hline $\mathrm{G}$ & A & 68.00 & 130.67 & 68.00 & & 71.00 & & 1.82 & 106.00 \\
\hline B & B & 50.67 & 119.13 & 55.00 & & 57.33 & & 0.62 & 86.67 \\
\hline $\mathrm{C}$ & B & 71.33 & 146.67 & 62.00 & & 64.33 & & 2.40 & 99.67 \\
\hline $\mathrm{D}$ & B & 70.00 & 154.20 & 66.33 & & 71.67 & & 2.20 & 106.00 \\
\hline $\mathrm{E}$ & B & 65.33 & 145.80 & 68.33 & & 72.67 & & 1.93 & 106.00 \\
\hline $\mathrm{F}$ & B & 64.00 & 144.03 & 64.33 & & 67.33 & & 1.37 & 104.00 \\
\hline G & B & 68.67 & 137.00 & 67.00 & & 70.33 & & 1.59 & 105.00 \\
\hline $\mathrm{C}$ & $\mathrm{C}$ & 49.33 & 88.27 & 53.33 & & 55.67 & & 0.29 & 86.67 \\
\hline $\mathrm{D}$ & $\mathrm{C}$ & 65.33 & 134.87 & 66.00 & & 69.33 & & 1.85 & 106.00 \\
\hline $\mathrm{E}$ & $\mathrm{C}$ & 60.67 & 135.57 & 65.00 & & 68.33 & & 1.94 & 104.67 \\
\hline $\mathrm{F}$ & $\mathrm{C}$ & 78.00 & 157.27 & 69.67 & & 73.00 & & 1.59 & 109.33 \\
\hline G & $\mathrm{C}$ & 61.33 & 132.53 & 63.67 & & 66.00 & & 1.78 & 102.00 \\
\hline D & D & 56.00 & 123.80 & 53.33 & & 55.33 & & 0.66 & 90.00 \\
\hline E & $\mathrm{D}$ & 57.33 & 146.47 & 67.00 & & 71.33 & & 0.95 & 103.67 \\
\hline F & D & 68.00 & 129.07 & 65.00 & & 68.00 & & 1.75 & 102.67 \\
\hline G & $\mathrm{D}$ & 56.00 & 125.13 & 66.67 & & 70.67 & & 1.27 & 104.67 \\
\hline $\mathrm{E}$ & $\mathrm{E}$ & 46.67 & 132.87 & 53.67 & & 56.00 & & 0.68 & 87.67 \\
\hline $\mathrm{F}$ & E & 64.67 & 148.17 & 64.33 & & 69.33 & & 1.83 & 104.00 \\
\hline G & E & 60.00 & 131.40 & 65.00 & & 68.00 & & 1.69 & 105.00 \\
\hline $\mathrm{F}$ & $\mathrm{F}$ & 55.33 & 163.87 & 53.00 & & 55.00 & & 0.51 & 93.00 \\
\hline G & F & 70.00 & 142.53 & 67.00 & & 70.67 & & 1.50 & 103.67 \\
\hline G & $\mathrm{G}$ & 59.33 & 129.73 & 54.33 & & 57.00 & & 1.13 & 93.00 \\
\hline
\end{tabular}

Dari Tabel 2 dinyatakan bahwa: (1) rata-rata terbesar data bobot 200 butir dari persilangan jagung yaitu 78 gram yang dihasilkan dari hasil persilangan tetua jantan Fdengan tetua betina C. Ratarata terkecil data itu yaitu 46.67 yang dihasilkan dari persilangan tetua jantan E dengan tetua betina E; (2) rata-rata terbesar data tinggi tanaman dari persilangan jagung yaitu 165.73 yang dihasilkan dari hasil persilangan tetua jantan D dengan tetua betina A. Rata-rata terkecil data itu yaitu 88.27 yang dihasilkan dari persilangan tetua jantan $\mathrm{C}$ dengan tetua betina $\mathrm{C}$; (3) Rata-rata terbesar data umur bunga jantan dari persilangan jagung yaitu 70 yang dihasilkan dari hasil persilangan tetua jantan $\mathrm{F}$ dengan tetua betina A. Rata-rata terkecil data itu yaitu 53 yang dihasilkan dari persilangan tetua jantan F dengan tetua betina F; (4) rata-rata terbesar data umur bunga betina butir dari persilangan jagung yaitu 75 yang dihasilkan dari hasil persilangan tetua jantan E dengan tetua betina A. Rata-rata terkecil data itu yaitu 55 yang dihasilkan dari persilangan tetua jantan $\mathrm{F}$ dengan tetua betina $\mathrm{F}$; (5) rata-rata terbesar data hasil jagung dari persilangan jagung yaitu 2.4 yang dihasilkan dari hasil persilangan tetua jantan $\mathrm{C}$ dengan tetua betina $\mathrm{B}$. Rata-rata terkecil data itu yaitu 0.29 yang dihasilkan dari persilangan tetua jantan $\mathrm{C}$ dengan tetua betina $\mathrm{C}$; (6) rata-rata terbesar data umur panen dari persilangan jagung yaitu 109.33 yang dihasilkan dari hasil persilangan tetua jantan $\mathrm{F}$ dengan tetua betina C. Rata-rata terkecil data itu yaitu 86.67 yang dihasilkan dari persilangan tetua jantan B dengan tetua betina $\mathrm{B}$ dan dari persilangan tetua jantan $\mathrm{C}$ dengan tetua betina $\mathrm{C}$.

\section{Anova Efek Daya Gabung Umum Dan Daya Gabung Khusus}

Berikut data anova daya gabung umum dan daya gabung khusus (Tabel 3). 
Tabel 3

Anova Gca Dan Sca Bobot 200 Butir

\begin{tabular}{lllll}
\hline Source & d.f. & JK. & M.S. & F \\
\hline Gca & 6 & 185,47 & 30,91 & 1,30 \\
Sca & 21 & 1303,47 & 62,07 & 2,61 \\
Error & 54 & 1283,78 & 23,77 & \\
Total & 81 & 2772.71 & & \\
\hline
\end{tabular}

Dari Tabel 3 dinyatakan sebagai berikut: Pertama, Fhitung Gca $=1.30$ dari bobot 200 butir lebih kecil dari $\mathrm{F}_{(0.05,6,54)}$ tabel $=2.272$ sehingga dapat dikatakan tidak ada perbedaan daya gabung umum di antara persilangan tetua. Sedangkan F hitung Sca $=2.61$ dari bobot 200 butir lebih besar dari $\mathrm{F}_{(0.05,21,54)}$ tabel $=1.754$ sehingga dapat dikatakan ada perbedaan daya gabung khusus diantara persilangan tetua.

Kedua, Fhitung Gca $=10.14$ dari tinggi tanaman lebih besar dari $\mathrm{F}_{(0.05,6,54)}$ tabel $=2.272$ sehingga dapat dikatakan ada perbedaan daya gabung umum diantara persilangan tetua. Sedangkan $\mathrm{F}$ hitung Sca $=7.10$ tinggi tanaman; lebih besar dari $\mathrm{F}_{(0.05,21,54)}$ tabel $=1.754$, sehingga dapat dikatakan ada perbedaan daya gabung khusus diantara persilangan tetua.

Ketiga, $\mathrm{F}$ hitung $\mathrm{Gca}=3$ umur bunga jantan lebih besar dari $\mathrm{F}_{(0.05,6,54)}$ tabel $=2.272$ sehingga dapat dikatakan ada perbedaan daya gabung umum diantara persilangan tetua. Sedangkan F hitung Sca $=13.37$ umur bunga jantan lebih besar dari $\mathrm{F}_{(0.05,21,54)}$ tabel $=1.754$ sehingga dapat dikatakan ada perbedaan daya gabung khusus di antara persilangan tetua.

Keempat, $\mathrm{F}$ hitung $\mathrm{Gca}=3.89$ umur bunga betina lebih besar dari $\mathrm{F}_{(0.05,6,54)}$ tabel $=2.272$ sehingga dapat dikatakan ada perbedaan daya gabung umum di antara persilangan tetua. Sedangkan $\mathrm{F}$ hitung Sca $=14.10$ umur bunga betina lebih besar dari $\mathrm{F}_{(0.05,21,54)}$ tabel $=1.754$ sehingga dapat dikatakan ada perbedaan daya gabung khusus diantara persilangan tetua.

Kelima, $\mathrm{F}$ hitung $\mathrm{Gca}=1.36$ hasil jagung lebih kecil dari $\mathrm{F}_{(0.05,6,54)}$ tabel $=2.272$ sehingga dapat dikatakan tidak ada perbedaan daya gabung umum diantara persilangan tetua. Sedangkan $\mathrm{F}$ hitung Sca $=11.06$ hasil jagung lebih besar dari $\mathrm{F}_{(0.05,21,54)}$ tabel $=1.754$ sehingga dapat dikatakan ada perbedaan daya gabung khusus diantara persilangan tetua.

Keenam, $\mathrm{F}$ hitung $\mathrm{Gca}=3.37$ umur panen lebih besar dari $\mathrm{F}_{(0.05,6,54)}$ tabel $=2.272$ sehingga dapat dikatakan ada perbedaan daya gabung umum di antara persilangan tetua. Sedangkan F hitung Sca $=25.80$ hasil jagung lebih besar dari $\mathrm{F}_{(0.05,21,54)}$ tabel $=1.754$ sehingga dapat dikatakan ada perbedaan daya gabung khusus diantara persilangan tetua.

\section{PENUTUP}

\section{Kesimpulan}

Dari hasil pembahasan hasil persilangan tanaman jagung yang meliputi bobot 200 butir, tinggi tanaman, umur bunga jantan, umur bunga betina, hasil jagung, dan umur panen dengan metode diallel pada dapat disimpulkan sebagai berikut:

Pertama, data bobot 200 butir tanaman jagung menunjukkan tetua $\mathrm{F}$ memiliki Daya gabung umum (Gca) yang terbesar, dan gca yang terkecil didapat dari tetua E. Daya gabung khusus (Sca) 
terbesar didapat dari persilangan tetua 2 dengan 6, dan Sca yang terkecil dari hasil persilangan tetua $\mathrm{B}$ dengan $\mathrm{D}$.

Kedua, dari data hasil persilangan tinggi tanaman jagung, Gca yang terbesar adalah dari tetua F, dan gca yang terkecil yang didapat dari tetua C. Sca terbesar didapat dari persilangan tetua A dengan $\mathrm{C}$, dan Sca yang terkecil didapat dari hasil persilangan tetua $\mathrm{D}$ dengan $\mathrm{E}$.

Ketiga, data umur bunga jantan tanaman jagung menyatakan bahwa Gca yang terbesar adalah yang didapat dari tetua A, dan Gca yang terkecil adalah yang didapat dari tetua C. Sca terbesar didapat dari persilangan tetua $\mathrm{B}$ dengan $\mathrm{F}$, dan Sca yang terkecil didapat dari hasil persilangan tetua E dengan $\mathrm{G}$.

Keempat, Gca umur bunga betina tanaman jagung terbesar didapat dari tetua A, dan Gca yang terkecil didapat dari tetua C. Sca terbesar didapat dari persilangan tetua B dengan C, dan Sca yang terkecil yang didapat dari hasil persilangan tetua $\mathrm{D}$ dengan $\mathrm{F}$.

Kelima, hasil biji tanaman jagung yang diperoleh dari tetua A dan B memiliki Gca terbesar dan yang terkcil dari tetua F. Sca terbesar didapat dari persilangan tetua $C$ dengan $D$, dan Sca yang terkecil didapat dari hasil persilangan tetua $\mathrm{E}$ dengan $\mathrm{G}$.

Keenam, Gca umur panen tanaman jagung terbesar didapat dari tetua A, dan Gca yang terkecil didapat dari tetua $\mathrm{B}$ dan tetua $\mathrm{C}$. Sca terbesar didapat dari persilangan tetua $\mathrm{B}$ dengan $\mathrm{F}$, dan Sca yang terkecil didapat dari hasil persilangan tetua $\mathrm{D}$ dengan $\mathrm{E}$.

\section{Saran}

Di bawah ini adalah beberapa saran untuk pengembangan selanjutnya: (1) berdasarkan nilai daya gabung umum, untuk keperluan persilangan dapat menggunakan tetua 6 untuk karakter bobot 200 butir dan tinggi tanaman; (2) apabila karakter umum berbunga betina dan jantan juga umur panen menjadi perhatian utama, tetua 1 dapat digunakan sebagai salah satu induk dari persilangan; (3) untuk karakter hasil jagung, tetua 1 dan 2 dapat digunakan sebagai induk persilangan.

\section{DAFTAR PUSTAKA}

Hardman, L. L. \& Gunsolus, J. L. (1998). Corn Growth and Development \& Management Information for Replant Decisions. MN Extension Service. Minnesota: University of Minnesota.

Paliwal, R. L. (2000). Tropical Maize Morphology. Tropical Maize Improvement and Production, p.13-20. Rome: Food and Agriculture Organization of the United Nations.

Singh, R. K. \& Chaudhary, B. D. (1979). Biometrical Methods in Quantitative Genetic Analysis, (2 ${ }^{\text {nd }}$ d.). New Delhi: Kalyani. 